\title{
IMPACT OF AGRIBUSINESS ENTREPRENEURIAL TRAINING ON ENTREPRENEURIAL ATTITUDES AMONG STUDENTS OF OYO STATE COLLEGE OF AGRICULTURE AND TECHNOLOGY, IGBOORA, OYO STATE, NIGERIA
}

\author{
Oyeronke A. Adekola ${ }^{1}$, Ajibola A. Ishola ${ }^{2 *}$ \\ ${ }^{1}$ Department of Agricultural Extension and Rural Development, Federal University of Agriculture Abeokuta, \\ Nigeria. \\ ${ }^{1}$ Department of Psychology,University of Ibadan, Nigeria.
}

Corresponding author: Ajibola Ishola Email: ajibola_ishola@yahoo.co.uk

\begin{abstract}
The study explores the impact of Agribusiness entrepreneurial training on entrepreneurial attitudes among students of Oyo State College of Agriculture and Technology (OYSCATECH), Igboora. The study was a cross-sectional design. 132 students offering entrepreneurship education in Agriculture were sampled using a selfreport questionnaire and multi-stage sampling. The larger percentage $(88.6 \%)$ of the respondents were below the age of 25 years, studying Science, management, agriculture engineering and Agriculture management based courses. 52.3\% were females and $47.7 \%$ were males. Data was analysed using descriptive statistics, Pearson correlation analysis and multiple regression analysis at $\mathrm{p} \leq 0.05$. Results reveals that students benefitted from vocation training such as fish production $(93.2 \%)$; Egg/Broiler production $(92.4 \%)$, Fish hatchery management (93.9\%), Piggery/Rabbit production (93.9\%), Fish processing and value addition (92.4\%) and Grain/crop production $(90.9 \%)$. The entrepreneurship skills benefitted include business start-ups $(85.6 \%)$, managerial coordination (92.4\%), book keeping and accounting, (84.8\%) among others. Entrepreneurship skills acquired, its perceived adequacy and value correlated significantly with entrepreneurship attitudes. Entrepreneurship skills acquired and its perceived value were significant predictors of attitude towards entrepreneurship while the role of adequacy of entrepreneurship skills was negligible. It was concluded that Agricultural entrepreneurship skills acquired and its perceived value were factors motivating entrepreneurship attitude among students.
\end{abstract}

Keywords: agriculture business, entrepreneurship education, entrepreneurial attitude, entrepreneurial intention

http://dx.doi.org/10.21776/ub.agrise.2020.020.2.4

Received 17 January 2020

Accepted 11 April 2020

Available online 30 April 2020

\section{INTRODUCTION}

Creation of entrepreneurship is crucial to ensuring economic prosperity in Nigeria. In Nigeria, entrepreneurship is becoming a driving force for economic growth. The international drive for this undertaking is rapidly spreading across world countries. The recognition of the high level of unemployment and the changing complexity of the economy has resulted in a driving factor resulting in increased incentives for youth entrepreneurial initiatives (Mahendra, Djatmika \& Hermawan, 2017). Aminu (2019) set that a large number of tertiary training graduate are jobless following quite a long while of leaving school.

Business enterprise is seen as an effective way of tackling unemployment problems as expanding number of business entrepreneurs among the masses is related with expanded thriving economy and diminished degree of joblessness (Mahendra et al., 2017). Effort in the past aimed at building the entrepreneurship potential of the youth and creating wealth resulting in the formulation of polices leading to the establishment of agencies and implementation of programs (Afolabi, 2015). 
Many programs such as National Directorate of Employment (NDE), Community Banks, Cooperative Banks and lately skill acquisition programs by various levels of government and nongovernmental organizations were implemented (NISER, 2009). Certain interventions cover young people in agriculture, women in agriculture and exposure to soft loans for small scale and cottage industries (Afolabi, 2015). To increase the percentage of people with entrepreneurial interest in addition to reducing the teeming population of the unemployed in Nigeria, the government instituted a policy on education for entrepreneurship in tertiary education in Nigeria with the aim of increasing entrepreneurial intention among tertiary students, which in turn is capable of producing entrepreneurs who can create jobs or reduce the number of youths looking for a job (Alao Alabi, Oketoyini and Famakinwa, 2018). The purpose is an important element in the initiation of entrepreneurship and has a major impact on business accomplishment (Mahendra et al., 2017).

Enterprise is a key driver of any country's economy (Alao et al. 2018). Ekore and Okekeocha (2012) pointed out that entrepreneurial professions would allow young graduates to become financially independent while contributing to employment, creativity and economic growth. The potential of a country to produce and maintain a steady flow of jobs is the product of innovation practices in different fields (Teru, 2015). Alao et al. (2018) observes that entrepreneurship implies that an individual is able to find potential opportunities and handle the resources needed in the business environment to take advantage of those opportunities. The broad range of business opportunities that it provides, in general due to its multifaceted and multipurpose existence, are among the other opportunity in the agriculture sector. The agricultural sector business enterprise identified by Alao et al. (2018) as all business entities involved in the production, supplying of inputs, agroprocessing, marketing and distribution of agricultural commodities. This applies to backward ties to farming, finance procurement, equipment, fertilizers, plants and so forth, at the input end as well as the manufacturing and distribution of products / products at the export end. As a modern form of agriculture businesses' of Nigeria's economy. It was noted that between 2003-2004 and nearly 25 per cent of domestic goods exportations (126.1 billion in 2003-2004), and by 2010 the biggest manufacturing sector, accounting for nearly 46per cent of total retail spending, were agribusinesses accounted for 12.1 per cent of GDP
(2003-2004). It is predicted that the role of entrepreneurship education will provide a theoretical basis for entrepreneurship principles, shaping an entrepreneur's mentality, disposition, and actions.

Entrepreneurship education is a knowledgebased structure that has two aspects, start-ups and venture development, as well as the ability to generate productive activities with its own resources (Mahendra et al., 2017). Implementing the learning process for entrepreneurship is also intended to improve the psychomotor environment by presenting students with tasks to produce new and innovative goods and undertake new business practices. It is anticipated that these practices will inspire the creativity of students. Entrepreneurial curriculum is supposed to drive the choice of students to do things leading to needs fulfilling, happiness participating, and disparity elimination by setting up a business or sector (Zimmerer et al., 2008). Students who have received training in entrepreneurship are likely to have a more positive mindset. Entrepreneurial attitude is the ability of a person to continuously react to an entrepreneur's own attributes (Meredith, 2005). The entrepreneurial mindset of students can be influenced by training in entrepreneurship that inspires learners to do something successful that was the goal in line with their entrepreneurial capability development. Therefore, an important character in shaping a human mentality and actions is the entrepreneurial attitude to be able to demonstrate their entrepreneurial purpose. Entrepreneurial intent is an eagerness to successfully carry out productive activities that direct individuals to use and execute important new enterprise ideas (Krueger et al., 2000).

In terms of entrepreneurship education, the understanding of students is shaped and formed by external influences that underpinning the development of their entrepreneurial ambitions. From the Theory of Planned Conduct as stated by Ajzen (2005), this insight can be seen suggesting that the purpose was influenced by the conduct of an individual. The goal of entrepreneurship is not hereditary, but through education it can be learned and created. It is in line with Athayde's (2009) view that the educational programs that build awareness of entrepreneurship as a career option can positively shape entrepreneurial attributes. It is in accordance with Athayde's (2009) belief that the educational programs that create understanding of entrepreneurship as a career choice will profoundly mold entrepreneurial qualities. Past research sources discussed the entrepreneur's personal situation and 
social context. Through implementing the Reasoned Action Theory (Azjen, 1991), one method used to analyze pre-entrepreneurial event actions is to concentrate on entrepreneurial goals. Intention is a good predictor of expected actions, according to Alam, Kousar and Rehman (2019). Through nature, business activity comes within the context of malicious actions (Armitage \& Conner, 2001). This move is particularly important for program planners and policy makers if the aim to include university curriculum entrepreneurship studies is to raise the occurrence of entrepreneurship after college.

According to Perterman and Kennedy (2003), for effectiveness of programs and policies in enhancing entrepreneurial behavior, a thorough knowledge of the factors influencing and shaping the decision of a person to engage in entrepreneurship is crucial. Research has shown that formal entrepreneurial education may impact students ' attitudes towards entrepreneurship decision. Thus, the study addresses the attitude of students towards entrepreneurship and motivating factors in starting their own business after graduation than only looking for job opportunity which later on helps is minimizing the unemployment rate (Alams et al., 2019; Alao et al., 2019). Therefore, this study is embarked upon to investigate the attitude of youth towards entrepreneurship development among youth. The main objective of the study is to assess the perception of youth towards entrepreneurial skills' acquired and attitude towards entrepreneurship among OYSCATECH students in Igboora. Specific objectives are to;

1. Identify agricultural ventures entrepreneurship programs the respondents attended during the current school year.

2. Determine the qualities developed in the respondents through management education system.

3. Examine the relationship between attitude of students towards entrepreneurship and intentions.

\section{RESEARCH METHODS}

The study was cross-sectional study. The Oyo State College of Agriculture and Technology (OYSCATECH), Igbooora was established in August 2006 with the objectives of providing another educational avenue for the training of youths especially in the area of middle level man power for the agricultural and technological sectors.

The Oyo State College of Agriculture and Technology is an autonomous public institution with the general functions of providing liberal higher education in various area of agriculture, technology and other related disciplines and to encourage food sufficiency and self-employment for youth in particular and Nigeria in general.

The population of the study is the student of college. The population of this study was estimated as 4789 students who were, at the time of the survey (2018/19 academic session). However only 201 students offer entrepreneurship education courses. In determining the sample size, the researchers used the Taro Yamane (1967) method which estimates 142 sample size for the study. This was scaled up to 150 to cover for attrition in the study.Multi stage sampling technique was used to select the participants for the study.

From the Six faculties in Oyo State College of Agriculture and Technology students that engaged in entrepreneurship skill were randomly selected. At second stage, $20 \%$ percent of total sample size was allotted to each faculty made up of six faculties. Random selection sampling techniques was used to select 25 students each from each of the faculty listed in the study. Entrepreneurship education was offer for 1 semester each year for student in the Ordinary National Diploma (OND) and Higher National Diploma (HND) programme. The curriculum contains trade skills, managerial skills and business ventures. The students who took their second semester Agribusiness entrepreneurship education were sampled after their examination. Questionnaire was use to elicit information from student of OYSCATECH in the study area. The questionnaire was divided into five sections.

The question was semi-structured it captures students vocational courses/Agriculture venture participated in; the enterprise skills taught in the scheme; adequacy of the courses on the enterprise skills; perceive valued derived from the entrepreneurship education and Attitude towards entrepreneurship were measured using items adapted from Alam et al. (2019) entrepreneurship attitude $(\alpha=0.92)$, motivation $(\alpha=0.89)$ behavior $(\alpha=0.82)$ scales The reliability coefficient of the questionnaire by test-retest was 0.84 . The participants responded to the items using a 5-point Likert scale ( $1=$ strongly disagree, $5=$ strongly disagree), bivariate response format (Yes or No) and open ended formats. The overall reliability in the present study was 0.91 alpha.

Students were approached during the classes. The researcher explain to the students that the questionnaire is for research purposes. They were assured that the information would be treated confidentially. Student who consented participated. 140 questionnaire was retrieved however only 132 
was useable in the study. Data was analyzed using descriptive statistics such as frequency counts, percentage and mean. Hypothesis was analyzed using in inferential statistics such as Pearson Product Moment Correlation (PPMC) and Multiple regression analysis at $\mathrm{p}<.05$ level of significance.

\section{RESULTS AND DISCUSSION}

\section{Results}

Table1: Distribution of the respondent based on socio-demographics characteristics

\begin{tabular}{|c|c|c|c|}
\hline Variables & Category & Frequency & Percent \\
\hline \multirow[t]{4}{*}{ Age } & $15-20$ years & 59 & 44.7 \\
\hline & $21-25$ years & 58 & 43.9 \\
\hline & 26-30 years & 13 & 9.8 \\
\hline & 31 years and above & 2 & 1.5 \\
\hline \multirow[t]{2}{*}{ Sex } & Male & 63 & 47.7 \\
\hline & Female & 69 & 52.3 \\
\hline \multirow[t]{2}{*}{ marital status } & Single & 125 & 94.7 \\
\hline & Married & 7 & 5.3 \\
\hline \multirow[t]{4}{*}{ level } & ND I & 15 & 11.4 \\
\hline & ND II & 65 & 49.2 \\
\hline & HND I & 29 & 22.0 \\
\hline & HND II & 23 & 17.4 \\
\hline \multirow[t]{2}{*}{ Religion } & Christianity & 93 & 70.5 \\
\hline & Islam & 39 & 29.5 \\
\hline \multirow[t]{14}{*}{ Department } & Computer science & 25 & 18.9 \\
\hline & Science lab Technology & 35 & 26.5 \\
\hline & Fisheries & 10 & 7.6 \\
\hline & Public Administration & 8 & 6.1 \\
\hline & Business Administration & 10 & 7.6 \\
\hline & Office Technology Management & 9 & 6.8 \\
\hline & Agriculturalbio-environmental & 1 & .8 \\
\hline & Agricultural Extension and Management & 10 & 7.6 \\
\hline & Computer Engineer & 12 & 9.9 \\
\hline & Forestry & 2 & 1.6 \\
\hline & Home and rural economics & 5 & 3.8 \\
\hline & Post-harvest technology & 1 & .8 \\
\hline & Animal health production & 2 & 1.5 \\
\hline & Crop production and technology & 1 & .8 \\
\hline \multirow{6}{*}{$\begin{array}{l}\text { family history of } \\
\text { entrepreneurship }\end{array}$} & Non & 91 & 68.94 \\
\hline & Trading & 17 & 12.88 \\
\hline & Business Oriented & 9 & 6.82 \\
\hline & Farming /Poultry/ Crop Production & 7 & 5.30 \\
\hline & $\begin{array}{l}\text { Artisan Electrician/ Art and Design/ } \\
\text { Barbing/ Fashion Designing }\end{array}$ & 8 & 6.06 \\
\hline & Total & 132 & 100.0 \\
\hline
\end{tabular}

Source: Primary data analyzed, 2019

Table 1 shows that $88.6 \%$ of the respondents were below the age of 25 years, $9.8 \%$ were between 26-30 years while $1.5 \%$ were 31 years and above. Most of the respondents were in science based courses (computer science (18.9\%), science lab technology $(26.5 \%)$, fisheries department $(7.6 \%)$, , Other departments represented include management (public administration (6.1\%), business administration (7.6\%), office technology and management $(6.8 \%)$ ) agriculture engineering (Agric bio-environmental engineering $(0.8 \%)$, post-harvest technology $(0.8 \%)$ Crop production and technology $(0.8 \%)$ and Computer engineering $(9.9 \%)$ ) and Agriculture management (agricultural extension and management $(7.6 \%)$, forestry $(1.6 \%)$ home and rural economics (3.8\%), Animal health production (1.5\%) while more than half of the respondents $(52.3 \%)$ were female and $47.7 \%$ were males. Larger percentages of the respondents $(94.7 \%)$ were single 
while $5.3 \%$ were married. 11.45 of the respondents were in National Diploma I, $49.2 \%$ were in National Diploma II, 22.0\% were in Higher National Diploma I while $17.4 \%$ were in Higher National Diploma II. Larger percentage of the respondents $70.5 \%$ were
Christian while 29.5\% were Muslims. Family history of entrepreneurship revealed that $12.88 \%$ were from family of traders, $6.82 \%$ from family of business consultants, $5.30 \%$ were family of farmers and $6.06 \%$ were from families of artisans.

Table 2. Agricultural business vocation programs offered

\begin{tabular}{lcc}
\hline \multicolumn{1}{c}{ Programs } & No & Yes \\
\hline Fish nutrition and feed formation & $9(6.8 \%)$ & $123(93.2 \%)$ \\
Eggs/Broiler production & $10(7.6 \%)$ & $122(92.4 \%)$ \\
Fish hatchery management & $8(6.1 \%)$ & $124(93.9 \%)$ \\
Piggery/Rabbit production & $8(6.1 \%)$ & $124(93.9 \%)$ \\
Fish processing/value addition & $10(7.6 \%)$ & $122(92.4 \%)$ \\
Grain/Crop production & $12(9.1 \%)$ & $120(90.9 \%)$ \\
\hline
\end{tabular}

Source: Primary data analyzed, 2019

Table 2 shows that the distribution of Agricultural business vocation the students benefitted from. These include fish nutrition and feed formation (93.2\%); Egg/Broiler production
(92.4\%), Fish hatchery management (93.9\%), Piggery/Rabbit production (93.9\%), Fish processing and value addition (92.4\%) and Grain/crop production $(90.9 \%)$.

Table 3. Entrepreneurship skills acquired

\begin{tabular}{lcc}
\hline \multicolumn{1}{c}{ Programs } & No & Yes \\
\hline Business startup (how to start) & $19(14.4 \%)$ & $113(85.6 \%)$ \\
Managerial ability (how to coordinate) & $10(7.6 \%)$ & $122(92.4 \%)$ \\
Where to source good and cheap materials & $29(22.0 \%)$ & $103(78.0 \%)$ \\
Book keeping and accounting & $45(34.1 \%)$ & $87(65.9 \%)$ \\
Negotiation skills & $20(15.2 \%)$ & $112(84.8 \%)$ \\
Packaging of products & $38(28.8 \%)$ & $94(71.2 \%)$ \\
Production skills & $24(18.2 \%)$ & $108(81.8 \%)$ \\
Promotion and advertisement & $27(20.5 \%)$ & $105(79.5 \%)$ \\
Marketing segmentation and distribution & $36(27.3 \%)$ & $96(72.7 \%)$ \\
Relating with customers and suppliers & $21(15.9 \%)$ & $111(84.1 \%)$ \\
Resource management & $9(6.8 \%)$ & $123(93.2 \%)$ \\
\hline
\end{tabular}

Source: Primary data analyzed, 2019

The pattern of content of the entrepreneurship programme reported include business start-ups (85.6\%), managerial coordination (92.4\%), procurement (source good and cheap materials) (78.0\%); book keeping and accounting, (84.8\%), negotiation skills $(84.8 \%)$, packaging of products $(71.2 \%)$ reported that there were, production skills (81.8\%), promotion and advertisement (79.5\%), marketing segmentation and distribution (72.7\%), customer relations (how to relate with customers and suppliers) $(84.1 \%)$ and resources management $(93.2 \%)$.

Table 4 depicted the perceived adequacy of the entrepreneurship skills received. More than half of the respondents reported receiving adequate knowledge in resource management (61.4\%), business coordination $(60.0 \%)$, business start-up $(56.1 \%)$, negotiation skills $(53.8 \%)$, procurement
(52.3\%), production skills $(50.8 \%)$, promotion and advertisement (49.2\%), while the less reported were adequacy of knowledge about customer relations (48.5\%), book keeping and accounting (45.5\%), products packaging $(43.9 \%)$ and marketing segmentation and distribution $(31.8 \%)$.

Table 5 reveals that $44.7 \%$ of the respondents believe that the present entrepreneurial education inculcate creativity and innovativeness in to them. The larger percentage (77.2\%) agreed that entrepreneurial education offers positive view of dignity in labor $(78.8 \%)$, allows flexibility in pursuit of economic sustainability $(78.8 \%)$. Further, the respondents generally believe that the entrepreneurial education instill in them high selfesteem (77.2\%), initiative taking ability (75.0\%), knowledge for commercial and legal aspect of business $(77.3 \%)$ and high need for achievement 
$(72.8 \%)$. The respondents also noted that the entrepreneurial education motivates in them the need to influence others $(71.2 \%)$, need for power (76.5\%), optimism $(75.0 \%)$, problem solving attitude $(79.6 \%)$ and risk taking ability (71.2\%).
Hypothesis I: There is no significant relationship between entrepreneurship skill, information and skill about entrepreneurship, management system, Perceived value of the entrepreneurship skills and attitude toward entrepreneur. The hypothesis was tested using Zero order correlation and the result presented in Table 6.

Table 4. Perceived adequacy of entrepreneurship skills

\begin{tabular}{lcc}
\hline \multicolumn{1}{c}{ Programs } & No & Yes \\
\hline Business startup how to start & $7(5.3 \%)$ & $51(38.6 \%)$ \\
Managerial ability (how to coordinate) & $14(10.6 \%)$ & $38(28.8 \%)$ \\
Where to source good and cheap materials & $12(9.1 \%)$ & $51(38.6 \%)$ \\
Book keeping and accounting & $16(12.1 \%)$ & $56(42.4 \%)$ \\
Negotiation skills & $18(13.6 \%)$ & $43(32.6 \%)$ \\
Packaging of products & $18(13.6 \%)$ & $58(43.9 \%)$ \\
Production skills & $11(8.3 \%)$ & $54(40.9 \%)$ \\
Promotion and advertisement & $9(6.8 \%)$ & $58(43.95)$ \\
Marketing segmentation and distribution & $23(17.4 \%)$ & $67(50.8 \%)$ \\
Relating with customers and suppliers & $11(8.3 \%)$ & $57(43.2 \%)$ \\
Resource management & $10(7.6 \%)$ & $41(31.1 \%)$ \\
\hline
\end{tabular}

Source: Primary data analyzed, 2019

Table 5: Perceived value obtained through entrepreneurship education

\begin{tabular}{lccccc}
\hline \multicolumn{1}{c}{ Values } & $\begin{array}{c}\text { Strongly } \\
\text { Disagree }\end{array}$ & Disagree & Undecided & $\begin{array}{c}\text { Agree } \\
\text { Strongly } \\
\text { Agree }\end{array}$ \\
\hline Creativity and innovativeness & $18(13.6 \%)$ & $41(31.1 \%)$ & $16(12.1 \%)$ & - & $57(43.2 \%)$ \\
Dignity for labor & $5(3.8 \%)$ & $7(5.3 \%)$ & $18(13.6 \%)$ & $51(38.6 \%)$ & $51(38.6 \%)$ \\
Flexibility & $9(6.8 \%)$ & $5(3.8 \%)$ & $14(10.6 \%)$ & $63(47.7 \%)$ & $41(31.1 \%)$ \\
High self esteem & $12(9.1 \%)$ & - & $18(13.6 \%)$ & $39(29.5 \%)$ & $63(47.7 \%)$ \\
Initiative taking ability & $10(7.6 \%)$ & $9(6.8 \%)$ & $14(10.6 \%)$ & $42(31.8 \%)$ & $57(43.2 \%)$ \\
Knowledge for commercial & $14(10.6 \%)$ & $2(1.5 \%)$ & $14(10.6 \%)$ & $41(31.1 \%)$ & $61(46.2 \%)$ \\
and legal aspect of business & & & & & \\
Need for achievement & $4(3.0 \%)$ & $15(11.4 \%)$ & $17(12.9 \%)$ & $48(36.4 \%)$ & $48(36.4 \%)$ \\
Need for influencing other & $8(6.1 \%)$ & $8(6.1 \%)$ & $22(16.7 \%)$ & $44(33.3 \%)$ & $50(37.9 \%)$ \\
Need for power & $9(6.8 \%)$ & $7(5.3 \%)$ & $15(11.4 \%)$ & $43(32.6 \%)$ & $58(43.9 \%)$ \\
Optimism & $8(6.1 \%)$ & $8(6.1 \%)$ & $17(12.9 \%)$ & $36(27.3 \%)$ & $63(47.7 \%)$ \\
Problem solving attitude & $2(1.5 \%)$ & $7(5.3 \%)$ & $18(13.6 \%)$ & $45(34.1 \%)$ & $60(45.5 \%)$ \\
Risk taking ability & $12(9.1 \%)$ & $11(8.3 \%)$ & $15(11.4 \%)$ & $25(18.9 \%)$ & $69(52.3 \%)$ \\
\hline
\end{tabular}

Source: Primary data analyzed, 2019

Table 6: Zero order correlation showing the relationship between entrepreneurship skill, information and skill about entrepreneurship, management system, and perceived value of the entrepreneurship skills on attitude toward entrepreneur

\begin{tabular}{|c|c|c|c|c|c|c|}
\hline & Mean & SD & 1 & 2 & 3 & 4 \\
\hline Attitude towards entrepreneurship & 65.72 & 12.96 & - & $.477 * *$ & $.463 * *$ & $.337 * *$ \\
\hline Entrepreneurship skill acquired & 19.89 & 2.34 & & - & $.680 * *$ & $.188^{*}$ \\
\hline Perceived adequacy entrepreneurship skills & 26.39 & 3.74 & & & - & $.430 * *$ \\
\hline Perceived value of the entrepreneurship skills & 59.62 & 10.96 & & & & - \\
\hline
\end{tabular}

Source: Primary data analyzed, 2019

Table 6 shows that there was significant positive relationship between entrepreneurship skill acquired $(\mathrm{r}=.48, \mathrm{p}<0.05)$, perceived adequacy of entrepreneurship skills $(\mathrm{r}=.46, \quad \mathrm{p}<0.05)$, and perceived value of entrepreneur $(r=.34, p<0.05)$ and attitude toward entrepreneur. This shows that increase in level of entrepreneurship skills competency acquired, perceived adequacy of 
information and skill about entrepreneurship, perceived value of the entrepreneurship skills will significant increase attitude toward entrepreneur. The second hypothesis stated that Perceived value of the entrepreneurship skills, entrepreneurship skill acquired, Perceived adequacy Information and skill about entrepreneurship will have significant joint and independent prediction on attitude towards entrepreneurship among students.This hypothesis was tested using multiple regression analysis and result summary presented in Table 7 .

Table 7: Multiple regression analysis showing the influence of Perceived value of the entrepreneurship skills, Entrepreneurship skill, Information and skill about entrepreneurship on Attitude towards entrepreneurship

\begin{tabular}{llllllll}
\hline \multicolumn{1}{c}{ Predictors } & $\beta$ & $\mathrm{t}$ & Sig. & $\mathrm{R}$ & $\mathrm{R}^{2}$ & $\mathrm{~F}$ & Sig. \\
\hline Entrepreneurship skill acquired & .343 & 3.358 & .001 & & & & \\
Perceived Adequacy Information and skill & .138 & 1.246 & .215 & .55 & 30 & 18.25 & $.000^{\mathrm{b}}$ \\
Perceived value of the entrepreneurship skills & .213 & 2.566 & .011 & & & & \\
\hline
\end{tabular}

Dependent Variable: Attitude towards entrepreneurship

Source: Primary data analyzed, 2019

Results presented in Table 7 reveal that Perceived value of the entrepreneurship skills , entrepreneurship skill, Information and skill about entrepreneurship significantly jointly predicted attitude towards entrepreneurship $\left(\mathrm{R}^{2}=0.26\right.$, $\mathrm{F}(3,128)=45.810, p<.01)$. It was thus revealed that the combination of entrepreneurship skills and it perceived benefits accounted for the $30 \%$ of the total variance observed in Attitude towards entrepreneurship. The result further revealed that entrepreneurship skill acquired $(\beta=.34, \mathrm{t}=3.36$, $p<.05)$ and perceived value of the entrepreneurship skills $(\beta=.21, \mathrm{t}=2.57, p<.05)$ were significant predictors of attitude towards entrepreneurships. However, the perceived adequacy information and skill was not a significant independent predictor of attitude towards entrepreneurship. The stated hypothesis was therefore accepted.

\section{Discussion}

This study examined the perception of youth towards entrepreneurial skills acquisition. It was discovered that both male and female students where involved while most them were singles. They all practice entrepreneurship and have vivid understanding about the study. Most of active age group below the age of 30 years. The study reveals that most of the students do not have family history of entrepreneurship but they were all involved in entrepreneurship activities during their school session.

They all have business mindset and high experience on managerial abilities and how to run a business. Agricultural business ventures the students benefitted from include fish production and its management, poultry production, Piggery/Rabbit production and Grain/crop production. This agricultural business have been identified to have easier economic viability and easier to start. Many investors consider more economically desirable projects with quick payback cycles, especially in economies that lack financial facilities (Olapade, Bangura, Tholley \& Momoh, 2017). This will raise higher returns on investment and early repayment of investment costs and enable farmers to welcome creativity (Olapade, et al., 2017).

Business start-ups, managerial coordination procurement, book keeping and accounting, business promotion and advertisement and customer relations were the major skills acquire from Agricultural business ventures. This findings demonstrated the important role of education is counted in socializing individuals into entrepreneurial careers, through entrepreneurship courses student knowledge about starting new business venture in a better and faster way the that result in more value from the identical opportunity (Davidsson \& Honig, 2013; Zhao et al., 2012;).

The provision of adequate information on business start-up, business management and coordination, promotion and advertisement was noted by the respondents in the study. This demonstrated that the entrepreneurship curriculum were well planned and implemented by the school. These findings agrees with Undiyaundeye, and Otu (2015) which identified that entrepreneurship curriculum has its own special methods to learning and teaching as must include creative learning options and pragmatic approach such as on site learning and visitations by experts. These build the young people trust in their entrepreneurial potential and be motivated as a consequence in their future.

The present entrepreneurial education was reported to improve creativity and innovativeness, positive view of dignity in labor, high self-esteem, initiative taking ability, knowledge for commercial and legal aspect of business and high need for achievement. This finding agrees with research 
done by Astuti and Martdianty (2012), Kolvereid and Isaksen (2006) who have shown that one's value in society in entrepreneurship and climate is strongly connected to entrepreneurial intentions.

There was significant positive relationship among entrepreneurship skill acquired, perceived adequacy of entrepreneurship skills, and perceived value of entrepreneur and attitude toward entrepreneur. Level of entrepreneurship skills competency acquired, perceived adequacy of information and skill about entrepreneurship, perceived value of the entrepreneurship skills were associated with positive attitude towards entrepreneurship. This findings also agrees with Zimmerer et al., (2008) That well-planned entrepreneurial education has been shown to fuel students' decision to engage in needs-related activities, contribute to satisfaction, and reduce unemployment by opening up a business or commercial enterprise. Training in entrepreneurship has been shown to be a driving force in the same phenomenon in entrepreneurship intentions and positive attitude towards early uptake among students (Alao et al. 2018).

A key motivation allow young graduates to become financially independent while contributing to employment, creativity and economic growth (Ekore \& Okekeocha, 2012). This is in agreement with studies that demonstrate that students who have been taught displayed a more optimistic approach to entrepreneurship (Meredith, 2005). The findings of this research indicated the skills gained in entrepreneurship and perceived value of the entrepreneurship skills were significant predictors of attitude towards entrepreneurships. However, the role perceived adequacy information and skill was negligible in influencing in attitude towards entrepreneurship. The findings is in agreement with Fayolle, Gailly and Lassas-Clerc (2016); Henderson and Robertson (2014); Zhang, Duysters, and Cloodt (2013) empirically demonstrated the entrepreneurial education as an important determinant of entrepreneurial intentions.

The results further align with Owusu-Ansah and Poku (2012) who showed that more than two-thirds of students subjected to entrepreneurship education were mostly or partially inspired to start company start-ups, and respondents thought they had the knowledge and expertise to create and run their own businesses.

\section{CONCLUSION AND SUGGESTIONS}

Conclusively, the study revealed that rate of unemployment among youth is alarming and indicates entrepreneurship as a way out in other to improve the economy and to develop student's ability in setting their career right, job creation and self-sustainability.

The findings of the study imply that there should be increased call for entrepreneurship education amongst secondary and tertiary institutions in other to instill fundamental understanding about entrepreneurship among youth to reduce unemployment and to have an effective economy in the future. Based on the finding of this study, the following recommendation were made:

1. The tertiary agricultural institutions should make entrepreneurship education mandatory and provision of good and standard entrepreneurial facilities for secondary schools and institutions.

2. Government should provide new approaches to entrepreneurship education for the youths, to include new innovations on how to start a business and know the legal aspect of running a business enterprise, provision of funds, loans and grants in other to start their own business.

Character of participants, including the opportunity to practice and experience real practical training and improve their entrepreneurial skills. The role of entrepreneurship training is a core for education which influences students through cooperative learning, experimentation, imagination and networking, in improving their skills. This will help students predict and predict future business opportunities. It is suggested that the course of entrepreneurship should be delivered interactively in order to accommodate students ' participation in the entire study process.

\section{REFERENCES}

Afolabi A. (201); The effect of entrepreneurship on economy growth and development in Nigeria. International Journal of Development and Economic Sustanability. 3(2):49-65.

Ajzen, I. (1991). The Theory of Planned Behavior. Organizational Behavior and Human Decision Processes, 50(2), 179-211. https://doi.org/10.1016/07495978(91)90020-T

Ajzen, I. (2005) Attitudes, Personality and Behaviour. 2nd Edition, Open University Press, Berkshire 
Alam, M. Z., Kousar, S., \& Rehman, C. A. (2019). Role of entrepreneurial motivation on entrepreneurial intentions and behaviour: theory of planned behaviour extension on engineering students in Pakistan. Journal of Global Entrepreneurship Research, 9(1). doi:10.1186/s40497-019-0175-1

Alam, M. Z., Kousar, S., \& Rehman, C. A. (2019). Role of entrepreneurial motivation on entrepreneurial intentions and behaviour: theory of planned behaviour extension on engineering students in Pakistan. Journal of Global Entrepreneurship Research, 9(1). doi:10.1186/s40497-019-0175-1

Alao O. T. Alabi, D. L, Oketoyini A. B. and Famakinwa M. (2018) Assessment of Agribusiness Entrepreneurial Interest among undergraduates in Selected Universities in Osun State, Nigeria. International Journal of Agriculture and Development Studies (IJADS) 3(1), 74-80.

Aminu, A. (2019) Characterising Graduate Unemployment in Nigeria as Educationjob Mismatch Problem African Journal of Economic Review, 7(2) 113-130.

Asmara, H. W., Djatmika, E. T., \& Indrawati, A. (2016). The Effect of Need for Achievement and Risk Taking Propensity on Entrepreneurial Intention through Entrepreneurial Attitude. Journal of Business and Management, 18(6), 117-126. http://doi.org/10.9790/487X180601117126.

Astuti, R. D., \& Martdianty, F. (2012). Students' entrepreneurial intentions by using theory of planned behavior, the case in Indonesia. The South East Asian Journal of Management,6(2), 100-143.

Athayde, R. (2009). Measuring Entreprise Potential in Young People. Entrepreneurship Theory \& Practice, 33(2), 481-500. https://doi.org/10.1111/j.15406520.2009.00300.x

Basardien, F., Friedrich, C., \& Twum-Darko, M. (2016). Evidence-Based Practices of Promoting Entrepreneurship Education in Higher Education Institutions in Africa. Journal of
Economics and Behavioral Studies, $8(5), 68-81$.

Chigunta, F. (2002). Youth Entrepreneurship: Meeting The Key Policy Challenges [Online]. Available: http://www.bg.entrep.ta (Accessed June 2019)

Davidsson, P. \& Honig, B. (2003) 'The Role of Social and Human Capital Among Nascent Entrepreneurs', Journal of Business Venturing, 18(3): 301-331.

Ekore, J. O., \& Okekeocha, O. C. (2012). Fear of entrepreneurship among university graduates: A psychological analysis.International Journal of Management, 29, 515-524. Retrieved from www.internationaljournalofmanagement.c o.uk.

Farhangmehr, M., Goncalves, P., \& Sarmento, M. (2016). Predicting Entrepreneurial Motivation among University Students. Education + Training, 58(7/8), 861881. https://doi.org/10.1108/ET-012016-0019.

Fayolle, A., Gailly, B., \& Lassas-Clerc, N. (2016). Assessing the impact of entrepreneurship education programmes: a new methodology. Journal of European Industrial Training, 30(9), 701-720.

Firmansyah, A. H., Djatmika, E. T., \& Hermawan, A. (2016). The Effect of Adversity Quotient and Entrepreneurial Self-Efficacy on Entrepreneurial Intention through Entrepreneurial Attitude. Journal of Business and Management, 18(5), 45-55. http://doi.org/ 10.9790/487X1805014555.

Hägg, G., \& Kurczewska, A. (2016). Connecting the Dots: A discussion on Key Concepts in Contemporary Entrepreneurship Education. Education + Training, 58(7/8), 700714. https://doi.org/10.1108/ET-122015-0115

Hattab, H. W. (2015). The Impact of Entrepreneurship Education on Entrepreneurial Intentions of University Students in Egypt. The Journal of Entrepreneurship, 23(1), 1- 
18.https://doi.org/10.1177/097135571 3513346

Henderson, R., \& Robertson, M. (1999). Who wants to be an entrepreneur? Young adults'attitudes to entrepreneurship as a career. Education \& Training, 41(5), 236245.

Hussain, A., \& Norashidah. (2015). Impact of Entrepreneurial Education on Entreprenerial Intention of Pakistani Students. Journal of Entrepreneurship and Business Innovation, 2(1), 4353.https://doi.org/10.5296/jebi.v2i1.75 34

Ibrahim, W. N. A., Bakar, A. R., Asimiran, S., Mohamed, S., \& Zakaria, N. S. (2015). Impact of Entrepreneurship Education on the Entrepreneurial Intentions of Students in Technical and Vocational Education and Training Institutions (TVET) in Malaysia. International Education Studies, 8(12), 141-156. https://doi.org/10.5539/ies.v8n12p141

Jakubiak, M., \& Buchta, K. (2016). Determinants of Entrepreneurial Attitudes in Relation to Students of Economics and Non-Economics. Studia $i$ Materialy, 2(1), 1730.http://doi.org/10.7172/17339758.2016.21.2

Khalili, B., Tojari, F., \& Rezaei, M. (2014). The Impact of Entrepreneurship Training Course on the Development of Entrepreneurial Features. European of Academic Research, 2(9), 1194211953.

Kuttim, M., Kallaste, M., Venesaar, U., \& Kiis, A. (2014). Entrepreneurship Education at University Level and Students Entreprenerial Intentions. Journal Procedia - Social and Behavioral Sciences, $\quad$ 110, 658-668. https://doi.org/10.1016/j.sbspro.2013.1 2.910 .

Mahendra, A. M., Djatmika, E. T., \& Hermawan, A. (2017). The Effect of Entrepreneurship Education on Entrepreneurial Intention Mediated by Motivation and Attitude among Management Students, State
University of Malang, Indonesia. International Education Studies, 10(9), 61. doi:10.5539/ies.v10n9p61

Meredith, G. G. (2005). Kewirausahaan: Teori dan Praktek (terjemahan). Jakarta: PT Pustaka Binaman Passindo.

NISER. (2009). Study on Skills Development for the Informal Sector of the Nigerian Economy (Vol. 29). Retrieved from http://www.journals.cambridge.org/ab stract_S0001972000060666.

Olapade O.J., Bangura, H., Tholley, J.B. \& Momoh, R.R. (2017)Economic differential of integrated fish, rice cum piggery and fish, rice cum poultry production systems. African Journal of Food, Agriculture, Nutrition and Development, 17(3): 1232512342; DOI: 10.18697/ajfand.79.15670

Owusu-Ansah, W. \& Poku, K. (2012). Entrepreneurship education, a panacea to graduate unemployment in Ghana? International Journal of Humanities and Social Sciences, 2(15), 211-220.

Peterman, N. E., \& Kennedy, J. (2003). Enterprise Education: Influencing Students, Perceptions of Entrepreneurship. Entrepreneurship Theory and Practice, 28(2), 129-144. doi:10.1046/j.15406520.2003.00035.x

Raposo, M., \& do Paco, A. (2011). Entrepreneurship education: Relationship between education and entrepreneurial activity. Psicothema, 23(3), 453-457.

Rengiah, P., \& Sentosa, I. (2016). The Effectiveness of Entrepreneurship Education in Developing Entrepreneurial Intentions among Malaysian University Students: (a Research Findings on the Structural Equation Modeling). European Journal of Business and Social Sciences, $\quad 5(2), \quad 30-43$. https://doi.org/10.21859/eulawrev08063.

Teru S. (2015). Evaluation of the Impact of Entrepreneurship on Nigerian Economic Development. Pearl Journal of 
Management, Social Science and Humanities, 1 (4), 69-77,

Undiyaundeye, F., \& Otu, E. (2015). Entrepreneurship Skills Acquisition and the Benefits amongst the Undergraduate Students in Nigeria. European Journal of Social Science Education And Research, 2(3), 9-14. doi:10.26417/ejser.v4i1.p9-14

Wach, K., \& Wajciechowski, L. (2016). Entrepreneurial Intentions of Students in Poland in the View of Ajzen's Theory of Planned Behaviour. Entrepreneurial Business and Economics Review, 4(1), 83-94. https://doi.org/10.15678/EBER.2016.0 40106.

Weerakoon, W. M. P. G. C., \& Gunatissa, H. H. A. J. (2014). Antecedents of Entrepreneurial Intention (with Reference to Undergraduates of UWU, Sri Lanka). International Journal of
Scientific and Research Publications, 4(11), 1-6.

Yamane, T. (1967).Statistics, An Introductory Analysis, 2nd Ed., New York: Harper and Row.

Zhang, Y., Duysters, G., \& Cloodt, M. (2013). The role of entrepreneurship education as a predictor of university students' entrepreneurial intention. International Entrepreneurship and Management Journal.

Zhao, H., Seibert, S. E., \& Hills, G. E. (2012). The mediating role of self-efficacy in the development of entrepreneurial intentions. Journal of applied psychology, 90(6), 1265.

Zimmerer, T. W., Scarborough, N. M., Wilson, D., Kwary, D. A., (TRANS.), \& Fitriasari, D., (TRANS.) (2008). Essentials of Entrepreneurship and Small Business Management. (5 ed.) Jakarta: PT Salemba Empat. 
This page is intentionally left blank 